\title{
Imbalance of Power: Social Service Entrepreneurs' Experiences of Entrepreneur-Municipality Relationship
}

\author{
Tarja Niemelä̈, Sofia Kauko-Valli*
}

\begin{abstract}
We investigate the complex dynamics between social service entrepreneurs and social sector managers through the lens of network metaphor, utilizing our data on social service entrepreneurs' experiences of cooperation with municipalities. We examine what kinds of dependencies exist in the entrepreneur-municipality relationships and what kind of consequences these dependencies have on social service businesses run by entrepreneurs. Basing on the social service entrepreneurs experience, our findings suggest that while the cooperation with the municipality represents a prerequisite for success, their business represent only one alternative for the renewal of social service structures from the point of view of municipalities. In addition, the existence of legally enforced supervisory duties incorporates a considerable amount of power that influences areas of the entrepreneur-municipality relationships and interaction other than just those defined by the supervisory and regulatory rights.
\end{abstract}

Keywords: social service enterprise, public-private-partnerships, social service entrepreneurship, cooperation, network metaphors.

\section{INTRODUCTION}

This article highlights social service entrepreneurship as a particular form of entrepreneurial activity, one that emphasizes the role of public-private partnership as a context for cooperation and effective networking with municipalities. It seems that little attention has been paid previously to dependencies in cooperation between social service entrepreneurs and social sector managers. By applying metaphoric thinking (Kostera, 2008; Morgan, 1980; Sulkowski, 2011) and a range of network metaphors (Easton, 1992) we want to explore the cooperation relationship between social

\footnotetext{
* Tarja Niemelä, Ph.D., School of Business and Economics, University of Jyväskylä, PO Box 35, FIN-40014, Jyväskylä, Finland, tarja.niemela@jyu.fi.

** Sofia Kauko-Valli, Ph.D., School of Business and Economics, University of Jyväskylä, PO Box 35, FIN-40014, Jyväskylä, Finland, sofia.kauko-valli@jyu.fi.
} 
service entrepreneurs and social sector managers from the social service entrepreneurs' point of view.

Most Western countries are, to varying degrees, battling with a situation where some kind of reform is needed to continue producing high-quality social services that are affordable as well as attainable in the future (Blank, 2000; Blomqvist, 2004; Lin, 2009; Van Slyke, 2003). Both outsourcing and privatization of traditionally publicly provided services (Jensen and Stonecash, 2004) have been seen as a solution to the growing gap between available resources and pressing needs (Rissanen, Hujala, and Helisten, 2010). New forms of enterprises as well as public-private-partnerships are looked upon with heightened interest, and a better and more creative interplay between public and private actors is hoped for (Forrer et al., 2010; Neck, Brush, and Allen, 2009; McGahan, Zelner, and Barney, 2013) to solve challenges related to, among others, the environment, global economic turmoil and instability, heavily aging populations and other rapid changes. Previous discussion can be anchored to the New Public Management trend (Pollit, 1995) which has had also an increasing impact on care service provision as a part of a global management trend.

Entrepreneurship research has had multiple foci (Gartner 1990; Gartner et al., 2004; Krueger 2005), but a special call to focus on entrepreneurship in the public interest has already been issued (Klein et al., 2010; McGahan et al. 2013). Increasingly, entrepreneurship is considered as a driving force behind the expansion of the social service sector (Austin, Stevenson, and Wei-Skillern, 2006) as means to meet the growing welfare needs of nations. Welter (2011) speaks for many (Audretsch, 2012; Johannisson, 2011) by stressing that in entrepreneurship research economic behavior can be better understood if it is looked at within its historical, temporal, institutional, spatial, and social contexts. These contexts provide individuals with opportunities and set boundaries for their actions, but it is worth remembering that entrepreneurship itself can also impact these contexts (Mason and Harvey, 2013).

Today, there is an increasing discussion on the privatization of social services and in the international context the private agents (such as social service entrepreneurs) are often seen as the key actors in leading a move from welfare state towards welfare society (Rissanen, et al., 2010). We wanted to study the Finnish context as it is similar to the overall situation in Scandinavia in that the institutional power of private agents is still relatively weak and the whole field is rapidly developing. The production of social services in Finland has been largely monopolized by municipalities and other publicly funded organizations. Over the past decade, the demand for the pluralization of the production of services and more efficient utilization of the private sector have 
surfaced in the discussion on social policy in Finland. The increasing costs of maintaining a welfare state have led to competitive bidding for services and distribution of public responsibility. This has given rise to opportunities for social service entrepreneurship. However, the growth of private social service entrepreneurship has been rather modest. From the entrepreneurs point of view this is due to atypical market conditions created by the controlling power of state and municipalities and overall heavy regulation concerning public services (Lyytinen, 2005), i.e., markets are in many ways controlled by buyers (municipalities) and it is a buyer who defines the final price level. Central Finland was further chosen as a research area due to its geographic and structural variation as it gives good insight into other provinces in Finland as well.

Because we are interested in the view of social service entrepreneurs on their cooperative relationship with social sector managers we take a theoretical look at the relationship through the lens of Easton's four network metaphors: networks as relationships, structures, positions and processes. Empirically we provide insight into the complex dynamics between social service entrepreneurs and social sector managers by utilizing explorative data on social service entrepreneurs' experiences of cooperation with municipalities conducted in Finland. Our empirical research questions are: 1) What kinds of dependencies exist between social service entrepreneurs and social sector managers? 2) How and why are these dependencies formed? and 3) What kind of consequences do public-private-partnerships have for the profitability of social service enterprises?

The results of our study revealed that social service entrepreneurs feel that there is a need for deeper cooperation and dialogue between social service entrepreneurs and social sector managers. This cooperation calls for new ways to enhance the innovation capacity and demand-based development of social service entrepreneurship. Our findings further suggest that whereas for entrepreneurs the municipality represents a prerequisite for business success, for municipalities' entrepreneurs represent only one alternative among others for the renewal of social service structures. In addition, the existence of a legally enforced supervisory duty incorporates a considerable amount of power that influences areas of the entrepreneurmunicipality relationships and interaction other than just those defined by the supervisory and regulatory rights. Because our results revealed the effects of the imbalance of power between the municipality and the entrepreneurs, we saw how the cooperative relationships had many negative impacts on a practical level.

We propose that the network metaphors provide a rich and multidimensional framework to analyze the cooperative relationships 
of social service enterprises and municipalities. Policy objectives and the cooperation governance can strengthen, weaken or restructure the cooperative relationships in the social service sector. Due to this dynamics, we argue that social service entrepreneurship requires a new reality with new venture models as a solution for markets and hierarchies. We explain and address these results in three sections. First we discuss theoretical ground for the study by introducing the network metaphors we have applied. Second, we introduce our methodology. Third, we consider how our findings apply to current theory as well as how applicable they are for social service entrepreneurs and municipality decision-makers. We also discuss limitations and suggest future research directions.

Definitional foundation of this article follows. We use the term social service entrepreneurship to refer to businesses that operate in the social service sector, usually in close cooperation and collaboration with municipalities that are responsible for the service production as a whole. The term commissioner-supplier model refers to a process of service acquisition in which the organizing responsibility and the actual production of the service in question have been separated from each other. The commissioned services are supplied by an organization either within or outside the municipality, according to the contract between the municipality and the social service entrepreneur. Social service entrepreneur refers to an entrepreneur who supplies services according the commissioner's specific instructions. The service commissioner can be e.g. municipality government, the municipal manager and council, or commissioners that have received their authorization (e.g. boards). By social sector manager we refer to municipal official, namely social welfare directors in municipal. By cooperation we mean that the social service entrepreneurs and social sector managers both seek to achieve their own different ends as suppliers of services and as commissioners of services to their customers. The concepts of power and dependence are discussed more in-depth in a network metaphor analysis of this study. Power is the central concept in network analysis and one important model to realize the cooperation relationships between social service entrepreneurs and social sector managers (municipalities). Power is an ability to influence the decisions and actions or other and power is linked to dependence and interdependence in the cooperation relationship between social service entrepreneurs and social sector managers in their exchange formulations and processes. We have used the definition of dependency, as explained in the resource dependence theory, and the principal - agent theory in studying entrepreneurs' viewpoint on the cooperation relationships between social service entrepreneurs and 
social sector managers with the notion of equality with those of hierarchy and unequal distribution of power. We were interested in the ways in which the elements of co-operation reflect the positions suggested by the above-mentioned theories, that is, to what extent the supposed position as 'Principal' and the possible position of entrepreneurs as 'agents' corresponds with reality, and how the features of these positions become apparent in the experiences of social service entrepreneurs.

\section{LITERATURE REVIEW}

The widespread nature of networking has attracted considerable attention in management literature and has become a useful concept because of its ability to constitute a specific, generic model of economic exchange, spreading in a broad range of industrial settings (Jenssen and Nybakk, 2013; Kogut, 2000; Niemelä, 2004; Nohria and Eccles, 1992; Tsai, 2001) The relationships between social service entrepreneurs and the municipality can be looked at through the lens of agency theory. Agency theory is applicable in several settings, ranging from macro-level issues, such as regulatory policy, to microlevel dyad phenomena, such as impression management. The domain of agency theory is the relationships that mirror the basic agency structure of a principal and an agent who are engaged in cooperative behavior, but have differing goals and differing attitudes towards risk (Eisenhard, 1989).

In our study, agency theory serves as an interesting mirror to analyze the operating conditions and entrepreneurial action in which principal and agent are likely to have not only shared goals, but also conflicting goals and in which there are some special governance mechanisms that limit the agent's selfserving behavior. Accordingly, the principal-agent theory provides us with one theoretical model with which we can try to find solutions for cooperative resource dependencies and interdependencies created in economic relationships, such as commissioner-supplier is in our case study. Principalagency theory is concerned with finding out how a municipality (principal) can design a compensation system (a contract) which motivates social service entrepreneurs (agent) to act in the principal's interest. A principal-agent relationship arises when principal contracts with an agent to perform some tasks on behalf of the principal and these actions affect the welfare of both the principal and the agent (Petersen, 1993).

To sum up, the principal-agent relationships is interesting in varied ways, i.e., a) there is some uncertainty in the way the agent's action gets transformed into output and b) there is asymmetrical information - for example - the agent observes his/her own action but the principal is not sure whether the agent acts in the principal's interest. (e.g. Petersen, 1993) When the network 
relations are seen as serving the critical resources, the basis of power between actors is typically based on resource dependence. Organizations become interdependent with other organizations, in other words organizational behavior becomes externally influenced because the focal organization must attend to the demands of those in its environment that provide resources necessary and important for continuous survival (Pfeffer, 1982). Managers and entrepreneurs alike are trying to strike a balance between seeking to achieve autonomy from those holding power and controlling their action and seeking to reduce uncertainty by developing inter-organizational structures of coordinated behavior, based on interdependencies. (Pfeffer and Salancik, 1987) In this article, it is argued from the social service enterprises point of view to find a sufficient balance between (external) dependence and interdependence (or strategic autonomy), and autonomy which is equally necessary to create and maintain a stock of strategic resources for sustaining competitiveness not only for market nor for commissioner.

\section{Networks as relationships}

To begin with, we view relationships from different perspectives, such as mutual orientation, dependence, bonds and investments. Mutual orientation can be seen as cooperation required in order to gain joint and different ends from the same means or service production processes. Also mutually accepted and mutually held objectives and regulations of cooperation interactions, norms as operational conditions for interactions between suppliers and commissioners can advance to achieve both the economic and non-economic goals of the cooperation. As Easton (1992: 9) has put it, "by knowing a partner firm better and appreciating what they can do and have to offer it is possible to both reduce costs and increase sales". The absence of mutuality can also occur if either one of the cooperative partners suddenly changes the objectives of the cooperation or if the process of interactions is not satisfactorily managed by one or both of them.

The concepts of dependency and power are intertwined and are used here interchangeably in describing cooperative relationships and networking. The relationship in the commissioner-supplier model seems to be based on both competitive and cooperative interdependencies (Baraldi, Gressetvold, and Harrison, 2012) and imperatives. Power can be measured in terms of the larger firms influence on decision-making within the smaller firm in areas such as pricing or investment. In consequence, domination or control characterizes the form of network constitution (Szarka, 1990). Following this, due to the power of the network, a firm may be legally independent, but not necessarily de facto independent: its actions may be influenced or 
controlled from outside its legal boundaries. From the resource dependence theory points of view (Pfeffer and Salancik, 2003) the development of interorganizational power affects the activities of organizations. Processes of reciprocity or cooperation do not insulate practitioners from considerations of power (Brizzi and Langley, 2012; Grabhner, 1994). In contrast to the market model, in which power is seen as some kind of imperfection, the network model views power as a necessary ingredient in exploiting interdependencies, and this exploitation of interdependencies may be asymmetrical because the more powerful economic actors are able to frame decision by which the constraints and opportunities of their exchange partners are shaped (Grabhner, 1994).

Bonds between cooperative partners can vary and have economic, social, technical, logistical and for example time based dimensions (Easton, 1992). In Easton's (1992: 10) words: "strong bonds provide a more stable and predictable structure and one which is more likely to be able to withstand change". The partners are bonded by their own will with various rules, laws and physical contracts that are not always easy to dissolve. As it comes to relationships there certainly exists strong and weak relationships, but also potential and residual relationships that refer e.g. to non-economic or indirect relationships (Easton and Araujo, 1986) and network management (e.g. division of work).

Investments refer to returns including for example time spent in building good and trustful social relationships between cooperative partners. Cooperative relationships are vulnerable to tension of conflicts in terms of the expected outcomes of the cooperative relationships, when it comes to equality of shares of the benefits. The quality and amount of investments made by cooperative partners plays a crucial role. To conclude: economic relationships are also social in terms of social exchange (Aldrich and Whetten, 1981; Thorelli, 1986) and should call for mutual investments to build trustful bonds that provide a more predictable structure and relation to withstand the uncertainty and constant change in the markets (Easton and Araujo, 1992; Ring and Van de Ven, 1994).

\section{Networks as structures}

The structure in any industrial system implies specific behavior of individual firms and their various interdependencies. Each firm has its own role in creating new possibilities for new forms of relationships which also reduce uncertainty within the network. (Easton, 1992). Furthermore, agency theory depicts agency structure where a principal and an agent are engaged in cooperative behavior, but have differing goals and attitudes toward risk 
(Eisenhardt, 1989). Agency theory is applicable to a variety of settings, ranging from macro-level issues, such as regulatory policy, to micro-level dyad phenomena, such as impression management. According to Jensen (1983) agency theory can be seen as the foundation put into place to create a powerful theory of organizations, while Perrow (1986) claims that the theory is trivial and dehumanizing at best. Despite the differences and disagreements (Barney and Ouchi, 1986; Demski and Feltham, 1978; Eccles, 1985; Eisenhardt, 1989) agency theory gives us a valuable mirror to analyze the situations in which the principal and agent are likely to have not only shared but also conflicting goals and missions, and in which there are some special governance mechanisms at play limiting the agent's self-serving behavior. The agency structure (Petersen, 1993) has many effects from the point of view of cooperation that account for outcomes and performance of the enterprises. Both external and internal changes can further reframe the structure of the network relationships.

\section{Networks as positions}

The focus of position perspective lies on single firms not on the whole network as such. Easton (1992, p. 19) refers to Mattsson (1984) who defines a position as a "role that the organization has for other organizations that it is related to, directly or indirectly" and this implies a definition of social role which in turn suggests, according to Mattsson (1984) that "the firm is expected by other firms to behave according to the norms associated with the position". When it comes to relationships as positions, history tends to determine the prevailing positions in cooperation whereas the future may offer opportunities for change. It can be argued that positions provide a language to negotiate changes in network positions and cooperation patterns although positions are not easy to achieve or to defend.

\section{Networks as process}

Networking and cooperation processes are dominated by the power relationships and interest structures of cooperative partners (Easton, 1992). Cooperation relationships are asymmetrical in terms of power and interest structures. In a network or cooperation relationship strong bonds call for cooperation and weak bonds call for competition. Network processes are dominated by the distribution of power and interest structures that constantly change. From the management point of view some enterprises have better access and opportunities to acquire additional resources than others. In networks, cooperation and competition are typical for the existence of strong bonding of cooperation relationships. Competition can be replaced by rivalry 
for the control of resources. Changes in network relationships are a result of evolutionary developmental processes in interaction of enterprises. As Easton (1992, p. 23) puts it, "networks are stable but not static", which provides opportunities for innovation and renewal of both the structures and positions of cooperation interests between firms.

\section{RESEARCH METHODS AND DATA}

This article is based on data about the operating conditions, cooperative relationships and the inherent dependencies between entrepreneurs and social sector managers in a new context where the roles and relationships of the public and private partnerships in social service sector were just beginning to emerge in Finland. The data for this study was collected in 2005 as part of a larger research project, studying social service entrepreneurmunicipality cooperation relationships. Although the situation has changed somewhat during the last decade, the same issues of fragmentation, high levels of competition, scarce resources and need for innovativeness in creating sustainable services have remained.

The survey was designed to gather information about the operating conditions, needs and attitudes affecting the future development of social service entrepreneurship in Central Finland particularly from the social service entrepreneurs' point of view. The following open-ended questions were asked: What qualities describe a good and functional cooperation relationship with the local municipality? How would you like the relationship between your company and the municipality to develop in the future? Are there any other notions about social service entrepreneurship you would like to mention?

The questionnaire was planned by the experts of the research group and some questions had been adapted from the earlier national surveys on social and health service enterprises. The questionnaire was piloted on social service entrepreneurs $(n=3)$ for feedback before finalizing the survey. A total of 133 questionnaires were sent to social service entrepreneurs, who had registered themselves in the company register of the county of Central Finland or who had acquired a Business ID (Business Identity Code). After the initial round one additional reminder was sent. The questionnaire comprised mainly multiple choice questions and some open-ended questions. The data was analyzed both statistically and by qualitative content analysis. The applied statistical methods were, in connection with linear distributions, mutual correlation and chi-square testing. The software used in this study was SPSS. Accordingly, we also used qualitative methods, because we thought that by asking open-ended questions we could obtain real-life experiences 
of interaction and cooperation between social service entrepreneurs and social sector managers by using the lens of network metaphors. (Denzin, and Lincoln, 2000). The qualitative aspect of the analysis was important in terms of the interest in attitudes and power relations in general. Open-ended questions asked in this study allowed entrepreneurs to elaborate on their experiences of cooperation. The qualitative content analysis was done with InVivo software. To analyze and code cooperative relationships and their inherent dependencies basing on our case material we used four metaphors to approach the complex dynamics between social service entrepreneurs and social sector managers: relationships, structures, positions and processes as introduced by Easton (1992). Assessing the four metaphors as a research technic and approach accounts for the fact that cooperation between social service entrepreneurs and social sector managers deals with issues of mutual orientation, bonds, dependence and investments but also the structures, positions and processes as relationships which are to be important in our case setting.

Our final sample consists of $72(54 \%)$ social service entrepreneurs, covering a broad range of service branches (Table 1).

Table 1. The background data of social service entrepreneurs

\begin{tabular}{ll}
\hline The background data of social service entrepreneurs $(\mathbf{n}=\mathbf{7 2})$ \\
\hline Gender & Female $53(78 \%)$ and male $14(21 \%)$ \\
Average age & 46 years \\
Respondent's employment in the firm (in years) & $\bar{\chi}=7$ years (0-17 years) \\
Respondent has education related to the sector & $90 \%$ (yes) \\
Former employer of respondent by sector & Public (56\%), private (27\%), other (17\%) \\
Prior work experience & Public (84\%), private (50\%) \\
Firm established (year) & $\bar{\chi}=1998(1988-2005)$ \\
Turnover (last season) & $\bar{\chi}=158,000 €(984-800,000 €)$ \\
Main service area of the firm & $26.5 \%$ \\
Foster care & $23.5 \%$ \\
Home service, household management & $20.6 \%$ \\
Cleaning, meals, errand assistance & $16.2 \%$ \\
Child day care & $10.3 \%$ \\
Rehabilitation of mental illness patients &
\end{tabular}

26 per cent of entrepreneurs offered services for relocating children at risk, 23 per cent offered home care services for the elderly and a total of $16 \%$ concentrated on children's day-care services. Of the firms, 10 per cent offered rehabilitation services for mental health patients, and 10 per cent offered different mental stimulation and day-time activity services. These percentages represent the general distribution of the various branches of the social service sector in the county of Central Finland. To a large extent, the local actors who responded to the questionnaires were women (78\%) with 
a relatively short working history as entrepreneurs in the social service sector. The surveyed entrepreneurs employed three persons on average, with the overall range being between 0 and 27 employees. There was also variation in the turnover of businesses: 47 of the firms that responded (out of a total of 72) provided us with information of their latest accounting period. The turnovers varied between 9846 euros and 800000 euros, the average being 158000 euros. Qualitative descriptions of profitability of business showed that 28 per cent of respondents described it as "excellent" or "good", 63 per cent as "average" or "satisfactory", and 6 per cent as "barely adequate" or "weak". 90 per cent of the respondents had education related to social services.

\section{ANALYSIS AND RESULTS}

\section{Entrepreneurs experience of cooperation as relationships}

Our data revealed that the two-way cooperative relationship between the social service entrepreneurs and social sector managers can be seen very distinctly. Unlike cooperation and networking between equal, privately held firms, in our case the relationship between social service entrepreneurs and social sector managers is dominated by both the context of social services and the multiple roles municipalities play in the equation of service production. Entrepreneurs operate in a context where there is still a lot of attitudinal resistance and confusion when it comes to the role that private businesses should have in the public-private-partnerships.

From the point of view of the mutual orientation, entrepreneurs see the cooperation predominantly as a necessity in order to maintain a profitable business, whereas for the social sector managers, it appears as an opportunity to fulfill the municipal social service duties in a more cost-efficient way. The entrepreneurs in the social services sector largely see themselves as highly dependent on the operational prerequisites that they receive from the social sector managers. It is not only a question of resource dependence (i.e., cooperation in the form of bought services); it is as much a question of the conditions of entrepreneurship as dictated by the prejudiced views towards development in the sector (i.e., whether social services should be offered in entrepreneurial form at all).

Four out of five $(80 \%)$ social service entrepreneurs agreed with the statement that the relationship between their firm and the municipality is a crucial factor in their business operations. The stronger the entrepreneur's belief was in the growing importance of entrepreneurship-based social services, the more important the functioning of the municipal relationship 
was seen to be for the business to be successful. $\left(\chi^{2}(2, N=67)=45.1, d f=20\right.$, $\mathrm{p}=0.001)$. Those entrepreneurs who gave most optimistic estimates about the possibilities of growth in the importance of entrepreneurship-based social services as regards the municipal service production as a whole, stated also their own municipal relationship was based on a positive attitude of the municipality towards cooperation. $\left(\chi^{2}(2, N=67)=37.4, d f=20, p=0.010\right)$.

The dependence between the entrepreneur and the municipality that characterizes the social services sector is not only a prerequisite for profitable business; it is also an obstacle to the formation of genuine competitive settings and to the development of normal supply and demand mechanisms. There is a considerable imbalance of power inherent in the relationship between the social service entrepreneurs and social sector managers, which was reflected in the entrepreneurs' experiences of cooperation.

\section{Entrepreneurs experience of cooperation as structures}

For the municipalities, the entrepreneurs represent one possible alternative for the renewal of their service structure, whereas for the entrepreneurs, the social sector managers represent a prerequisite for business success. This setting unavoidably creates a hierarchy within the cooperation. Because of the insufficiently developed market demand, when trying to get involved with the market the social service entrepreneurs are bound to be the underdogs, and face a situation where they primarily compete not for the acceptance of their customers, but for that of their market competitor, the public sector. In its role as the financier, the municipality can set the conditions and take advantage of its power position in ways that leave only little choice to the entrepreneur. To attract a positive response from the decision-makers, entrepreneurs need to be ready to modify their service concept to fit the needs expressed by the decision-maker; a promise of quality that can win the trust of the commissioner must also be made.

The will of the social service entrepreneurs to provide services according to the conditions set by the municipality is not motivated only by financial needs but also by the fact that they are bound to do so by law. There were considerable differences in the ways in which the municipal supervisory and regulatory rights were exercised in different municipalities. The answers of the entrepreneurs showed a full spectrum of variation. However, in the answers of the social sector managers, uniformity is the dominant feature. According to them, the most common means to ensure that the supervisory duties are fulfilled include meetings, annual control visits and regular customer feedback procedures. Also the diversity of the existing supervisory policies was mentioned according to entrepreneurs as follows: 
"The quality of firm is supervised through visits by the social authorities and the health inspector, as well as through fire inspections." (Entrepreneur 59)

"Quality is supervised by checking that we have enough personnel considering the amount of children we take care of, and that our personnel is competent. On top of that there are also the visits and the inspections of the premises". (Entrepreneur 71)

"There are plans for a quality manual for the private sector. The county council also supervises the operation and the quality of the unit". (Entrepreneur 92)

"The municipality employees do not have any quality of their own!" (Entrepreneur 17)

Most of the respondents directed their criticism at the one-way nature of cooperation, the practices which, instead of fostering a dialog, tend to resemble a hierarchical 'take it or leave it' ultimatum. The entrepreneurs' will to become equal partners in the interaction is very much highlighted in the answers.

"The relationship should be developed more towards cooperation. The municipality should at least ask the entrepreneur about possible care placements, and also, the customers should be presented with the whole spectrum of available services, not forgetting the private service providers". (Entrepreneur 119)

"There is certainly a lot of work to be done in openness and communications". (Entrepreneur 28)

"The people in charge at the municipality should be interested in the private service provider. I have offered to come and present my services but not once have they found time in their schedules for that! Sharing and receiving information are the cornerstones of a functioning cooperation". (Entrepreneur 75)

They wish to become actors who, instead of the one-way right to be heard, have the right to be active partners and to make long-term service strategy plans within the cooperative relationship. When we asked the entrepreneurs about the turnover covered by the services bought by the municipality, it 
became apparent that only 9 out of $68(13 \%)$ respondents could get by on the customer demand created by the market. An analysis of the total amount of social services bought within the region revealed that $88 \%$ of the purchases were financed by the municipality and $12 \%$ by independent consumers.

\section{Entrepreneurs experience of cooperation as positions}

The municipality has the ultimate right to decide who is fit to operate in the field of social services and what kind of conditions a firm needs to meet in its operations in order to make its business profitable. The need for tailoring that is apparent within the branch is based both on the right of the buyer to define what is desired, and on the law-based supervisory duties of the municipality regarding the services they purchase. In this sense, the entrepreneurs' interest towards the development of the cooperation is fascinating: they have a distinct will to intensify cooperation and interaction, even though the relationship entails the regulatory right and supervisory role of the municipality.

When the focus of attention was extended to cover areas outside of the urban areas, the share of private market demand disappears completely from the total turnover percentages. Nearly one half $(43 \%)$ of the social service entrepreneurs who answered our survey were completely dependent on the municipalities' desire and ability to buy their services. On the practical level, this dependence may surface as a kind of a spontaneously activated control mechanism: the need of the service providers to maintain a working relationship with the municipality adds to the entrepreneurs' motivation to ensure both the quality of their services and the fulfilment of the service criteria as set by the municipality. The relationships with the municipality were characterized as "riddled with suspicion" and "distrustful": it looked like the municipal actors easily took on a domineering and patronizing role, which -in addition to their general attitude- was experienced as deficient, one-way communication. Entrepreneurs' felt that their opinions were only rarely listened to, and then only if it was profitable to the municipality. On the practical level, this silent discord became most apparent in conflicts in agreement policies and bidding competition processes - usually involving questions concerning the balance between quality and cost. Theentrepreneurs' demand for strengthening their profile is not only based on the need to become valued partners in a dialogue, but also (and predominantly) in their desire to develop their role as entrepreneurs creating profitable business.

"Cooperation should be uncomplicated and genuine. The entrepreneur should be aware of the needs of the municipality well in advance, so that the 
firm could tailor suitable services for the municipality. The cooperation should be open and happen in real-time". (Entrepreneur 114)

When estimates were made concerning the current profitability of the firm, those respondents that on the one hand considered the financial profitability of their firm to be very good felt that their current municipal relationship was based on a positive attitude of the municipality towards cooperation $\left(\chi^{2}(2, N=67)=17.51, d f=8, p=0.025\right)$. Those entrepreneurs who considered their profitability to be very good also thought that their own municipal relationship was based on the advantages of mutual cooperation $\left(\chi^{2}(2, N=67)=17.1, d f=8, p=0.029\right)$ and that, over the next few years, the relationship would develop further in a positive manner $\left(\chi^{2}(2, N=67)=17.7\right.$, $\mathrm{df}=8, \mathrm{p}=0.024)$.

\section{Entrepreneurs experience of cooperation as processes}

Entrepreneurs are fully aware of the fact that the demand for private-sector services on the social services market is not yet extensive enough to maintain profitable business. This is because the will to actually pay for such services is virtually non-existent. Citizens still hold a strong belief in the availability of free public welfare services and society including the decision-makers and the media generally supports the public sector as the primary source of social service production. In the social services sector, the criteria for buying services are not defined by the experience customers have from their earlier purchases. Instead, they are defined by the social sector managers who, when making the agreements on the buying of services, also set the options for choices available for the customers. It can also be statistically proven that a functioning municipal relationship bears considerable significance on the growth of the firm's familiarity within the municipality $\left(\chi^{2}(2, N=67)=34.6\right.$, $\mathrm{df}=20, p=0.022$ ). It can also be statistically proven that those entrepreneurs that evaluate the relationship between the development of the operating conditions of one's own firm place considerable significance on the necessity of developing the municipal cooperation $\left(\chi^{2}(2, N=67)=44.2, d f=20, p=0.001\right)$.

None of the customers of the said firms paid for their services themselves. Instead, they all held agreements to buy service from the entrepreneurs in question, paid fully by the municipality. The relationship between the municipality and the entrepreneur is quite vulnerable. In the light of our data it indeed seems obvious that the existence of a law-enforced supervisory duty incorporates a considerable amount of power, which will spread its influence also over other areas of the entrepreneur-municipality interaction than just that defined by the supervisory and regulatory rights. 


\section{DISCUSSION AND CONCLUSIONS}

This study contributes to the understanding of public-private partnerships as a context for cooperation with municipalities. To further our understanding of the experiences of social entrepreneurs' cooperation relationships with municipalities, we used network metaphors, mixed-methods analysis and our explorative data. We examined what kind of dependencies exist in the relationships between social service entrepreneurs and municipal decisionmakers from the social service entrepreneurs point of view, how and why these dependencies are formed and what kind of consequences they may have on the profitability of social service business. Our study focused on operational restrictions as dependencies and their effects on the conditions for entrepreneurial opportunities created by the demand-based market mechanism. This focus revealed, as it comes to social service entrepreneurs' experiences, that in the field of social service entrepreneurship, there is a need for deeper cooperation and dialogue between social service entrepreneurs and the social sector managers.

Our findings suggest, basing on the social service entrepreneurs experience, that although the municipality represents a prerequisite for social service entrepreneurs own business success, their business represent only one alternative for the renewal of social service structures from the point of view of municipalities. In addition, the existence of a legally enforced supervisory duty incorporates a considerable amount of power in the hands of the municipality. This concentration influences in turn other areas of the entrepreneur-municipality relationships and interaction, more than just those areas defined by the supervisory and regulatory rights. Because our results revealed the effects of the imbalance of power between the municipality and the entrepreneurs, we saw how the cooperative relationships had many negative impacts on a practical level.

Social service entrepreneurship is a promising field within entrepreneurship research due to its specific context, which inherently combines social, economic and historical (as attitudes, beliefs, and needs) perspectives. By looking at the phenomenon through the contextual lens as Welter (2011) and Watson (2013) suggest, we were given an opportunity to approach the research phenomenon in a new way. For example, in the stream of networking and cooperation theories there is a tendency to focus on the positive side of networking outcomes and often neglect the idea that there might also be a dark side to it.

Our main conclusions contribute to the research questions of the study as follows: 
What kinds of dependencies exist between social service entrepreneurs and municipality decision-makers relationship?

Entrepreneurs need the municipality to succeed in business. On the other hand, they are forced to shape their business concept according to decisions and wishes arising from the municipal sector. However, the relationship is not only one-sided. The municipality needs entrepreneurs to renew the business structure in social service sector.

How and why are these dependencies formed?

Citizens are used to enjoying free public welfare services offered by the public sector, a notion that is enforced by society including the decisionmakers and the media. Contemporary development is neither increasing the willingness of individuals to actually pay for welfare services nor is it beneficial to creating profitable business. The municipality as the financier can set the conditions and utilize the power position in ways that leave little choice to the entrepreneur. The municipality also ultimately decides who is fit to operate in the field of social services and how the business should be organized. This imbalance in demand and supply means that instead of customers deciding the services they want to buy, the decisions are made by social sector managers.

What kind of consequences may the decisions of the municipality have on the profitability of social service businesses?

The entrepreneurs in the social services sector largely regard themselves as highly dependent on the suggestions of the social sector managers. When entering a market, social services entrepreneurs are forced to compete for the acceptance of the public sector instead of the acceptance of the customers. Entrepreneurs are asked for adjustability, flexibility and high quality in their service concept to meet the needs expressed by the decisionmakers. In the welfare services sector the keys to prevent or enhance the diversification of the structuring are held by the social sector managers.

\section{LIMITATIONS}

When assessing the external validity of our research, it is important to consider some limitations our data may have. The results of our survey suffer, to an extent, from the fact that the sample was both relatively small and confined to a geographically limited area. However, in a country like Finland, where 
the traditions of public responsibility for welfare are strong, the number of social service enterprises is still relatively small regardless of geographical location. The small number of firms is admittedly accentuated in those areas where the population is the sparsest, and some of these areas were also found within the borders of the region of our research. Nevertheless, Central Finland represents the Finnish municipalities well, both in population density and the traditions of public services. Central Finland provides a thorough representation of the reality of the Finnish social service context, where strong traditions of public services and the more reform-oriented new aspirations are mixed in a fascinating way.

\section{IMPLICATIONS FOR PRACTICE AND FURTHER RESEARCH}

This study offers many new avenues for further research. Building on the theoretical underpinnings and the conceptual definitions introduced at the beginning of the article, we suggest increasing the focus on both the social and economic aspects of development possibilities of social service entrepreneurship. We would also like to reconsider how the social aspect is emphasized in social service entrepreneurship. How do social aspects affect decision-making and the dependencies in relationships of various forms of venture typologies and business platforms? What does the social aspect mean in cooperation relationships and how is it associated with the demandbased social service entrepreneurship? How does this kind of cooperation between entrepreneurs and municipalities call for new ways to enhance the innovation capacity and demand-based development of social service entrepreneurship?

It would also be interesting to study what kind of role and influence the social aspect has on social service entrepreneurship and its development. This should include examination of how the social aspect affects opportunities for building innovation capacity and utilizing effectual strategy in social service entrepreneurship. Theoretically it would be interesting to conceptualize the social aspects of building on the effectual logic of social service entrepreneurs.

When looked at from the social point of view, a further question emerges: Does the market failure and dependency between social sector managers and social service entrepreneurs call for a new business model and a whole new way of thinking and doing business versus the traditional, commercial way of doing business?

New social and wellness innovations are usually generated in the interface between different industry sectors in response to changing 
customer needs and market demand. There is a genuine call for diversifying products and services by allowing different venture forms to find their role in the field of social service production. Municipalities have the opportunity to have a significant impact on their own area by buying services from local companies, thereby supporting enterprises and encouraging the creation of new business and service models.

\section{References}

Aldrich H.E. \& Whetten, D. (1981). Organisation-set, action-sets and networks. Making the most of simplicity. In: P. Nystrom, W. Starbuck, (Eds.), Handbook of Organizational Design (pp. 385-408). Oxford University Press: New York.

Audretsch, D. (2012). Entrepreneurship Research. Management Decision, 50(5), 755-764.

Austin J.E. \& Seitanidi, M.M. (2012). Collaborative Value Creation: A Review of Partnering Between Nonprofits and Businesses. Nonprofit and Voluntary Sector Quarterly, 41(5), 726-758.

Austin, J., Stevenson, H. \& Wei-Skillern, J. (2006). Social and Commercial Entrepreneurship: Same, Different, or Both? Entrepreneurship Theory and Practice, 30(1), 1-22.

Baraldi, E., Gressetvold, E. \& Harrison, D. (2012). Resource interaction in inter-organizational networks: Introduction to the special issue. Journal of Business Research, 65(2), 123-127.

Barney, J. \& Ouchi, W. (Eds.). (1986). Organisational Economics. San Francisco: Jossey-Bass.

Blank, R. (2000). When Can Public Policy Makers Rely on Private Markets? The Effective Provision of Social Services. Economic Journal, 11(462), 34-49.

Blomqvist, P. (2004). The Choice Revolution: Privatization of Swedish Welfare Services in the 1990s. Social Policy Administration, 38(2), 139-156.

Brizzi, L. \& Langley, A. (2012). Studying processes in and around networks. Industrial marketing management, 41(2), 224-234.

Demski, J. \& Feltham, G. (1978). Economic incentives in budgetary control systems. Accounting Review, 53, 336-155.

Denzin, N.K. \& Lincoln, Y.S. (2000). Handbook of Qualitative Research. Thousand Oaks, CA: Sage.

Easton, G. \& Araujo, L. (1992). Non-Economic Exchange in Industrial Networks. In: G. Easton, L. Araujo (Eds.), Industrial Networks: A New View of Reality (pp. 62-84). London: Routledge.

Easton, G. (1992). Industrial networks: A Review. In: G. Easton, L. Araujo (Eds.), Industrial Networks: A New View of Reality (pp. 1-27). London: Routledge. 
Eccles, R. (1985). Transfer pricing as a problem of agency. In: J. Pratt, R. Zeckhauser (Eds.), Principals and agents: the structure of business (pp. 151-186). Boston: Harvard Business School Press.

Eisenhardt, K. (1989). Agency Theory: An Assessment and Review. Academy of Management Review, 14(1), 57-74.

Forrer, J., Kee, J.E. \& Newcomer, K.E. \& Boyer, E. (2010). Public-private partnerships and the public accountability question. Public Administration Review, 70(3), 475-484.

Gartner, W.B. (1990). What are we talking about when we talk about entrepreneurship? Journal of Business Venturing, 5, 15-28.

Gartner, W.B., Shaver, K.G., Carter N.M. \& Reynolds, P.D. (2004). Handbook of Entrepreneurial Dynamics: The process of business creation. Thousand Oaks, CA: Sage Publications.

Grabhner, G. (Ed.) (1994). The Embedded Firm on the Socioeconomics of Industrial Networks. London: Routledge.

Jensen, M. (1983). Organization Theory and Methodology. Accounting Review, 56, 319-338.

Jensen, P., Stonecash, R. (2004). The efficiency of public sector outsourcing contracts: a literature review. Melbourne Institute Working Paper.

Jenssen, J.I. \& Nybakk, E. (2013). Inter-organizational networks and innovation in small, knowledge-intensive firms: a literature review. International Journal of Innovation Management, 17(2), 1-27.

Johannisson, B. (2011). Towards a practice theory of entrepreneuring. Small Business Economics, 36, 135-150.

Klein, P.G., Mahoney, J.T., McGahan, A.M. \& Pitelis, C.N. (2010). Toward a theory of public entrepreneurship. European Management Review, $7(1), 1-15$.

Krueger, N.F. (2005). Sustainable entrepreneurship: Broadening the definition of "opportunity". SSRN Accepted Paper Series, 7: Entrepreneurship in a Diverse World.

Kogut, B. (2000). The Network as Knowledge: Generative rules and the emergence of structure. Strategic Management Journal, 21(3), 405425.

Kostera, M. (2008). Myth, Metaphor and Inspiration, In: M. Kostera (Ed.), Mythical Inspirations for Organizational Realities (pp. 9-15). London: Palgrave-Macmillan.

Lin, K. (2004). Sectors, Agents and Rationale: A Study of the Scandinavian Welfare States with Special Reference to the Welfare society Model. Journal of the Scandinavian Sociological Association, 47(2), 141-157.

Lyytinen, S.-M. (2005). Julkisen sektorin varjosta kunnallisen palveln täydentäjäksi: Sosiaalialan yrittäjyys Keski-Suomessa. In: T. Niemelä, S-M. Lyytinen, A. Palmroth, M. Jalkanen (Eds.), Puheenvuoroja yrittäjyydestä maaseudulla. Jyväskylän yliopiston taloustieteiden tiedekunnan julkaisuja, Julkaisuja 152. 
Mason, C. \& Harvey, C. (2013). Entrepreneurship: Contexts, opportunities and processes. Business History, 55(1), 1-8.

McGahan, A.M., Zelner B.A. \& Barney, J.B. (2013). Entrepreneurship in the public interest: Introduction to the Special Issue. Strategic Entrepreneurship Journal, 7(1), 1-5.

Morgan, G. (1980). Paradigmas, Metaphoras and Puzzle Solving in Organization Theory. Administrative Science Quarterly, 25, 605-622.

Neck, H., Brush, C. \& Allen, E. (2009). The Landscape of Social Entrepreneurship. Business Horizons, 52, 13-19.

Niemelä, T. (2004). Interfirm Cooperation Capability in the Context of Networking Family Firms: The Role of Power. Journal of Family Business Review, 17(4), 319-330.

Nohria, N. \& Eccles, R. (Eds.) (1992). Networks and Organizations: Structure, Form, and Action. Boston, MA: Harvard Business School Press.

Perrow, C. (1986). Complex Organizations. New York: Random House.

Petersen, T. (1993). The Economics of Organization: The Principal-Agent Relationship. Journal of the Scandinavian Sociological Association, 36, 277-293.

Pfeffer, J., Salancik, G.R. (2003). The External Control of Organizations. A Resource Dependence Perspective. Stanford, CA: Stanford University Press.

Pollitt, C. (1995). Justification by works of by faith? Evaluation, 1(2), 133154.

Ring, P.S. Van de Ven, A.H. (1994). Developmental processes of co-operative inter-organizational relationships. Academy of Management Review, 19(1), 90-119.

Rissanen, S., Hujala, A. \& Helisten, M. (2010). The State and future of social service enterprises - a Finnish case. European Journal of Social Work, 13(3), 319-337.

Szarka, J. (1990). Networking and Small Firms. International Small Business Journal, 8(2), 10-22.

Sułkowski, Ł. (2011). Types of metaphors of organization. Journal of Intercultural Management, 3(2), 221-227.

Thorelli, H. (1986). Networks: Between Markets and Hierarchies. Strategic Management Journal, 7(1), 37-51.

Tsai, W. (2001). Knowledge Transfer in Intraorganizational Networks: Effects of Network Position and Absorptive Capacity on Business Unit Innovation and Performance. The Academy of Management Journal, 44(5), 9961004.

Van Slyke, D. (2003). The Mythology of Privatization in Contracting for Social Services. Public Administration Review, 63(3), 296-315.

Watson, T.J. (2013). Entrepreneurial action and the Euro-American social science tradition: pragmatism, realism and looking beyond 'the entrepreneur'. Entrepreneurship \& Regional Development, 25(1-2), 1633. 
Welter, F. (2011). Contextualizing Entrepreneurship - Conceptual Challenges and Ways Forward. Entrepreneurship Theory and Practice, 35(1), 165184.

\section{Abstrakt (in Polish)}

W naszej pracy badamy złożonq dynamikę między przedsiębiorcami oferujq̨cymi usługi społeczne a menadżerami sektora społecznego za pomoca metafory sieci, używajqc danych dotyczqcych doświadczeń, jakie majq tacy przedsiębiorcy we wspótpracy z władzami lokalnymi. Badamy jakiego rodzaju zależności istnieja w relacji przedsiębiorca - władza lokalna oraz jakie konsekwencje zależności te majq na firmy prowadzqce działalność w sektorze usług społecznych. W oparciu o doświadczenia przedsiębiorców z tego sektora, wyniki naszych badań sugerujq, że o ile współpraca z władzami lokalnymi jest warunkiem niezbędnym powodzenia działalności, ich przedsiębiorstwa stanowiq tylko jednq alternatywę dla odnowienia usług społecznych z punktu widzenia władz lokalnych. Ponadto, istnienie narzuconych przez prawo obowiqzków nadzorowania zawiera w sobie znaczny ładunek władzy, która wpływa na relacje między przedsiębiorcami a władzami lokalnymi oraz interakcje inne niż te zdefiniowane prawami nadzoru i regulacjami.

Kluczowe słowa: przedsiębiorstwo oferujqce usługi społeczne, partnerstwo publiczno-prywatne, przedsiębiorczość usług społecznych, współpraca, metafory sieci.

\section{Biographical notes}

Tarja Niemelä, Ph.D, is a research professor at the School of Business and Economics; University of Jyväskylä. Her main area of research activity encompasses the issue of networking and cooperation, growth of the firm, venture creation and learning in organizations, while the main research interest is focused on rural entrepreneurship and family entrepreneurship. She is an experienced educator and trainer in a business school and other business organizations.

Sofia Kauko-Valli, Ph.D. is adjunct professor at the School of Business and Economics at the University of Jyväskylä, Finland. Her main area of research deals with subjective experience and construction of experience in the entrepreneurial context. Her research interests focus on psychology of entrepreneurship and positive psychological interventions. 